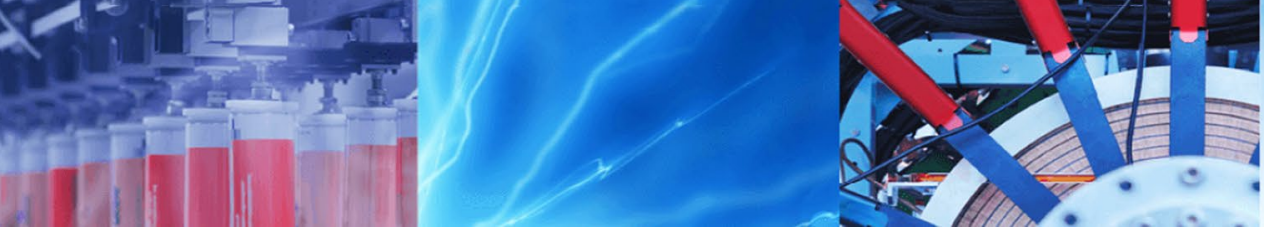

Research Article

\title{
Investigating the leaf area index changes in response to climate change (case study: Kasilian catchment, Iran)
}

\author{
Mohammad Reza Ramezani $^{1} \cdot$ Ali Reza Massah Bavani $^{2}\left[\right.$ Mostafa Jafari $^{3} \cdot$ Ali Binesh $^{4} \cdot$ Stefan Peters $^{5}$
}

Received: 14 September 2019 / Accepted: 18 February 2020 / Published online: 28 February 2020

(c) Springer Nature Switzerland AG 2020

\begin{abstract}
Vegetation cover plays an important role in the hydrologic cycle of Kasilian catchment in Iran. This study aimed to estimate leaf area index (LAI), as an important vegetation factor in hydrologic loses, in response to climate change in the future period (2020-2039) over Kasilian catchment located in the north of Iran. For this purpose, LAI was simulated by gridded BIOME-BGC in 319 pixels within the case study domain over the study period (2004-2013) for three dominant land covers of the Kasilian catchment including deciduous broadleaf forest (DBF), shrubs, and C3 grasses, and BIOMEBGC accuracy has been assessed using MODIS-derived LAI. Then, monthly projections of climate variables obtained from the average of 9 AOGCMs-AR5 in the future period (2020-2039) and annual projection of $\mathrm{CO}_{2}$ level from 2004 to 2039 under RCP2.6 and RCP8.5 scenarios were used to assess the impact of climate change on LAI. Results show that LAI will increase in response to the overall predicted rise in temperature, precipitation, and $\mathrm{CO}_{2}$ level under both scenarios in all pixels. This increase under the RCP8.5 scenario is predicted to be more than RCP2.6 scenario so that the mean LAI in Kasilian catchment will increase by $3.1 \%$ and $2.2 \%$ under RCP 8.5 and RCP2.6 scenarios, respectively. In addition, our analysis showed that DBF land cover will be more sensitive to climate change in this catchment.
\end{abstract}

Keywords Climate change $\cdot \mathrm{LAI}$ change $\cdot \mathrm{BIOME}-\mathrm{BGC} \cdot$ MODIS products

\section{Introduction}

The leaf area index (LAl) refers to the ratio of the total onesided green leaf area per unit area of ground $[3,45]$. LAl is a consumptive water term in hydrologic processes, which control the amount of water intercepted by leaf area. This vegetation variable plays an important role in hydrologic processes and water accounting in catchments $[13,33,53$, $59,63,64]$. Regarding the influence of LAI on eco-hydrology processes, investigating its changes in catchment scale is vitally important [48], and it enables hydrologists to estimate accurate water budget under climate change scenarios. Estimating LAI changes in response to climate change (temperature and precipitation changes) and atmospheric variable change (level of $\mathrm{CO}_{2}$ ) has been less considered in the ecological studies [40,49].

Climate variables, as a limiting factor, have a significant effect on plant growth $[7,15]$ so that recent researches have shown that humidity and warming of the climate have led to intensification of the plants' growth [16, 34]. Also, in areas with water scarcity, changes in plant growth and LAl are particularly dependent on the plant available water held in soil and atmosphere [65]. Besides, another effective factor in plant growth is the carbon dioxide level $\left(\mathrm{CO}_{2}\right)$ [18]. It has been proven that an increase in carbon dioxide level causes to increase the photosynthesis

$\triangle$ Ali Reza Massah Bavani, armassah@ut.ac.ir|'School of Engineering and Built Environment, Griffith University, Brisbane, Australia. ${ }^{2}$ Department of Irrigation and Drainage Engineering, Aburaihan Campus, University of Tehran, Tehran, Iran. ${ }^{3}$ Research Institute of Forests Rangelands, Agricultural Research Education and Extension Organization (AREEO), Tehran, Iran. ${ }^{4}$ Faculty of Civil Engineering and Built Environment, University of Newcastle, Newcastle, Australia. ${ }^{5}$ School of Natural and Built Environments, University of South Australia, Adelaide, Australia. 
rate and intensity of the plant growth [23]. Also, a study showed that an increase in carbon dioxide level contributes to LAl increase in grasses land cover [28]. Considering the strong interaction between LAl, climatic variables, and carbon dioxide concentration, it is expected that LAI would change in response to climatic and atmospheric changes in the future $[22,24]$. Previous studies showed that an overall increase in temperature, precipitation, and carbon dioxide level in the future would lead to LAI increase in a forested region, for a study case in Montana, USA [40]. In contrast, LAI is expected to decrease in the future, followed by precipitation drop and temperature rise in a catchment, located in southeastern Australia [49].

Modeling the relationships between LAI and environmental factors enables researchers to predict the interactions between them in different conditions, such as climate change [27]. To model these relationships, there is a simple method of making regression models between LAI and climate variables [5, 49]. However, these methods are not able to recognize the interaction between LAI and atmosphere as well as hydrosphere. A more accurate approach is using ecosystem models which simulate the flow of water, carbon, and energy in terrestrial ecosystems $[25,43,56]$. For example, BIOME-BGC is a well-known biogeochemical model. Its capability to simulate LAI has been demonstrated in several studies $[20,37,39,55,66]$.

Satellite-derived LAI which provides time series of LAI over large areas with the high spatial resolution has been used to assess the ecological model accuracy $[6,26,60]$. There are several satellite sources for estimating LAI such as MODIS (the Moderate Resolution Imaging Spectroradiometer) [31], CYCLOPES [1], and AVHRR (Advanced VeryHigh-Resolution Radiometer) [10]. MODIS LAl products are one of the most widely used LAI sources in ecological studies, and its reasonable accuracy has been demonstrated $[8,44,61,62]$. For example, to assess the BIOMEBGC performance in LAI simulation, MODIS annually maximum LAI [66] and MODIS monthly LAI [55] have been used in recent years. Moreover, MODIS LAI images have been used as initial input to different ecosystem models or as observed data for calibration of these models $[38,53]$.

In this study, our overall purpose is to understand how the LAI will change in response to climate and atmospheric changes in the future period in Kasilian catchment. In particular, our main objectives include (1) determining the vegetation conditions of the study area with an ecosystem model during the study period (2004-2013), (2) projecting the changes in climate and atmosphere variables in the future period (2020-2039) relative to baseline period (1986-2005), and (3) determining the LAl changes in response to climate and atmosphere changes under different scenarios of climate change in the future period (2020-2039) relative to the study period (2004-2013).

\section{Case study}

The geographic location of Kasilian catchment spans $35.58^{\circ}-36.07^{\circ} \mathrm{N}$ in latitude and $53.18^{\circ}-53.30^{\circ} \mathrm{E}$ in longitude, with a total catchment area of $68 \mathrm{~km}^{2}$ located in the mountainous lands of Mazandaran Province in the north of Iran (Fig. 1). The catchment elevation ranges from a minimum altitude of $1113 \mathrm{~m}$ on the northern part to a maximum altitude of about $3334 \mathrm{~m}$ in the southern part. Based on de Martonne's climate classification, the Kasilian catchment is characterized by the cold climate in southern zones and temperate climate in northern zones. According to a climate data recorded at the Darzikola climate station
Fig. 1 Location of case study in Iran and the location of stations in the case study

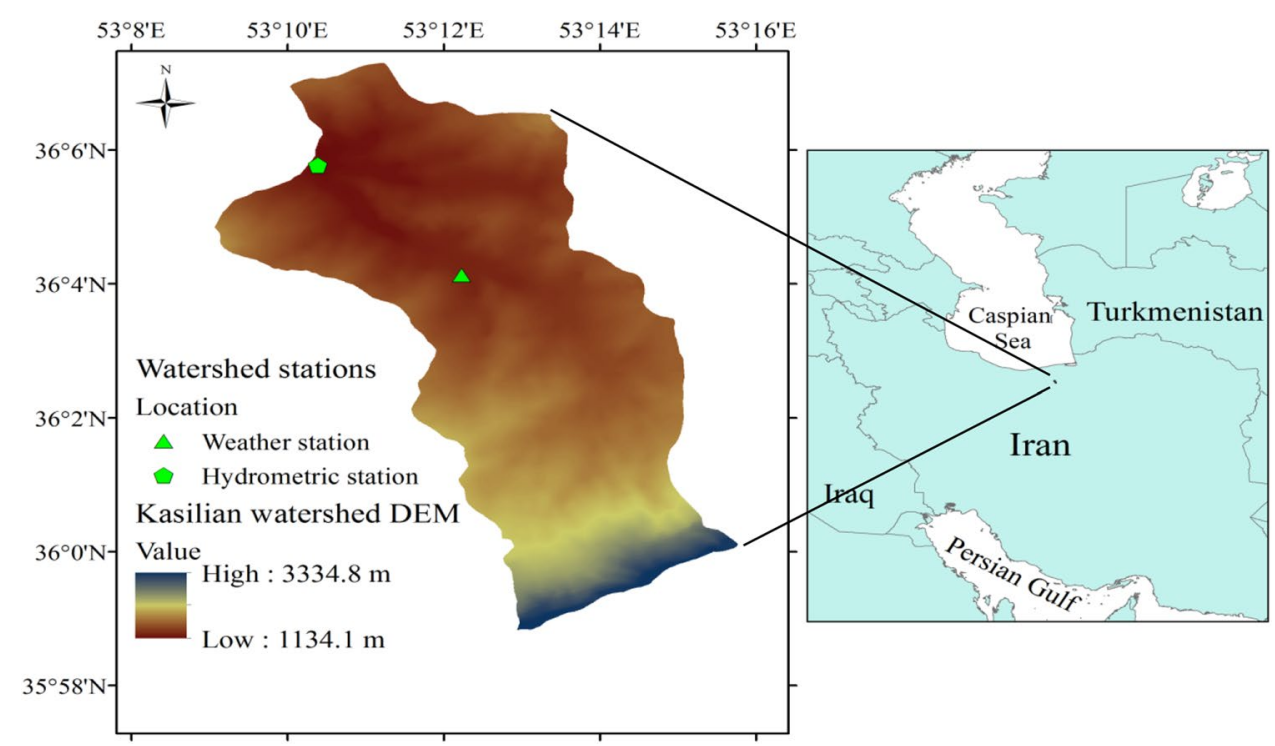


located in the center of the catchment, the mean annual precipitation and temperature (2004-2013) in the catchment are $700 \mathrm{~mm}_{\text {year }}{ }^{-1}$ and $12{ }^{\circ} \mathrm{C}$, respectively. Previous research by agriculture ministry of Iran in Kasilian catchment in 1995 showed that about $60 \%$ of Kasilian catchment is covered by dense forest, and the rest of the area is covered by pasture (20\%), croplands (15\%), and lands with sparse vegetation (5\%). Another study showed that about $80 \%$ of the trees in this forest consist of two broadleaf tree species including broadleaf beech trees (Fagus Orientalis) and hornbeam trees (Carpinus betulus), and both of them consist of a high interception rate [12]. Also, Kasilian catchment land cover, especially natural forest, plays a fundamental role in the formation of initial hydrologic losses rate [12].

Moreover, deforestation caused by anthropogenic activities resulted in a rise in the production of potential runoff in Kasilian catchment over four recent decades [21]. Although previous research investigated the land cover change scenarios in the past decades [11], land cover change in response to climate change in the future periods has never been investigated in Kasilian catchment.

\section{Materials and methods}

\subsection{BIOME-BGC model}

BIOME-BGC is a biogeochemical model which simulates main physiological processes such as photosynthesis, evapotranspiration, respiration, and decomposition within the terrestrial ecosystems $[39,51]$. The latest version of this model is BIOME-BGC version 4.2, which can simulate several vegetation indices such as NPP, GPP, and LAI for 7 vegetation cover types such as the evergreen needle leaf forest (ENF), evergreen broadleaf forest (EBF), deciduous needle leaf forest (DNF), deciduous broadleaf forest (DBF), shrubs, C3 and C4 grasses, based on temporal scales of daily, monthly, and annual. BIOME-BGC model calculates LAI by multiplying carbon allocated to leaves times the specific leaf area.
To simulate LAI using BIOME-BGC model with high spatial resolution, high-resolution land cover map and LAI values are needed. The only available land cover map in Kasilian catchment was related to the year 1995 and has a low spatial resolution of $2 \mathrm{~km}$, while we needed a vegetation map with a higher spatial resolution at the beginning of the study period (2004). Moreover, there were no available field-LAI measurements for the Kasilian catchment. To address these restrictions, MODIS land cover product named as MODIS MCD12Q1 [9] and MODIS LAI product named as MODIS MOD15A2H [32] which have the same spatial resolution $(500 \mathrm{~m}$ ) were used in this study. Using MODIS products enabled us to develop gridded BIOMEBGC with a spatial resolution of 500 m within Kasilian catchment, and consequently, 319 pixels were created over Kasilian catchment area.

The ecosystem process modeling using BIOME-BGC model includes two steps: In the first step, the model was run in a spin-up mode. Spin-up run is a common step for ecosystem models to ensure that it achieves stable ecosystem conditions in the desired site [52]. After achieving an equilibrium state, the model was run in normal mode. At this step, BIOME-BGC simulates carbon, nitrogen, and water cycles in the components of the plant and soil. BIOME-BGC model requires three main categories of information, including climatic data, environmental information, and eco-physiological parameters (Table 1). The climatic data in each pixel were simulated using the weather simulator of BIOME-BGC model called "Mountain Climate Simulator" (MT-CLIM model) [50]. Other environmental information of each pixel, including elevation, slope, slope's direction, and soil texture information (silt, clay, and sand), was obtained from a digital elevation model (DEM) and basin's soil map, respectively. These environmental data were re-gridded to a $500 \mathrm{~m}$ spatial resolution to enter the BIOME-BGC model.

Figure 2a shows the vegetation cover map in the study area in 2004. To use MODIS vegetation cover map information for the BIOME-BGC model, the obtained vegetation cover types were reclassified into available vegetation cover types in the database of BIOME-BGC model (Table 2).
Table 1 Input datasets for BIOME-BGC model

\begin{tabular}{lllll}
\hline Data & Temporal scale & Time span & Spatial scale & Data source \\
\hline Max and min temp & Daily & $2004-2013$ & Point & Darzikola climate station \\
Precipitation & Daily & $2004-2013$ & Point & Darzikola climate station \\
$\mathrm{CO}_{2}$ & Annual & $2004-2013$ & Point & Stocker et al. [46] \\
Soil & One-off & 2000 & Grid (1 km) & FAO-UNESCO \\
DEM & One-off & - & Grid (90 M) & Iran mapping organization \\
Land cover & One-off & 2004 & Grid (500 M) & MODIS MCD12Q1 \\
LAl & Monthly & $2004-2013$ & Grid (500 M) & MODIS MOD15A2H \\
Eco-physiological parameters & - & - & - & White et al. [57] \\
\hline
\end{tabular}




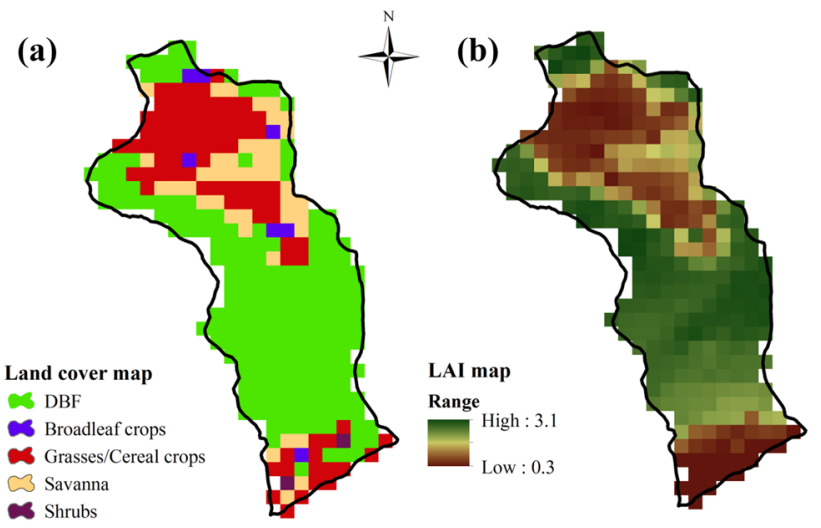

Fig. 2 a MODIS land cover map and b MODIS LAI map in Kasilian catchment

Table 2 Reclassification of MODIS land covers into BIOME-BGC database land cover

\begin{tabular}{ll}
\hline LAI/FPAR land cover classification & $\begin{array}{l}\text { BIOME-BGC } \\
\text { land cover } \\
\text { classifica- } \\
\text { tion }\end{array}$ \\
\hline Grasses and cereal crops & C3 grasses \\
Broadleaf crops & C3 grasses \\
Shrubs & Shrubs \\
Savanna & Shrubs \\
Deciduous broadleaf forest (DBF) & Deciduous \\
& broadleaf \\
& forest \\
(DBF)
\end{tabular}

Figure $2 \mathrm{~b}$ shows the average LAl map throughout the Kasilian catchment from 2004 to 2013. It is important to note that the accuracy of MODIS-derived LAI was not validated because there were no field-LAI measurements in Kasilian catchment. Lack of field-LAI measurements was a restriction in this study that might reduce the reliability of results. This restriction did not allow us to use other satellite imageries such as Landsat TM (with $30 \mathrm{~m}$ spatial resolution), which has a higher spatial resolution than MODIS images (with $500 \mathrm{~m}$ spatial resolution), because derived LAI from Landsat TM needs to be validated against fieldLAI measurements. Therefore, we used MODIS LAI product, in which its reasonable accuracy and reliability have been reported by many studies conducted in a different part of the world $[8,44,61,62]$.

\subsubsection{Evaluation of BIOME-BGC model}

To evaluate the gridded BIOME-BGC model accuracy, BIOME-BGC monthly LAI output was compared against monthly MODIS-derived LAI using three statistical criteria including $R^{2}$ (coefficient of determination), RMSE (root mean square error), and percent error (PE) shown in Eqs. (1), (2), and (3), respectively, where $X$ : the monthly MODIS LAI, Y: the monthly BIOME-BGC LAI, and N: the total number of monthly MODIS LAI $(N=120)$. Low quantities of RMSE and PE and high quantities of the coefficient of determination $\left(R^{2}\right)$ represent the acceptable accuracy of BIOME-BGC model.

$R^{2}=\frac{N \sum_{i=1}^{N} Y X-\left(\sum_{i=1}^{N} Y\right)\left(\sum_{i=1}^{N} X\right)}{\sqrt{N\left(\sum_{i=1}^{N} Y^{2}\right)\left(\sum_{i=1}^{N} Y\right)^{2}} \sqrt{N\left(\sum_{i=1}^{N} X^{2}\right)\left(\sum_{i=1}^{N} X\right)^{2}}}$

$\mathrm{RMSE}=\sqrt{\frac{\sum_{i=1}^{N}(Y-X)^{2}}{N}}$

$\mathrm{PE}=\left(\frac{\sum_{i=1}^{N}|Y-X|}{\sum_{i=1}^{N} Y}\right) \times 100$

\subsection{Climate change projections}

\subsubsection{Climate models}

At present, AOGCMs (atmosphere-ocean general circulation models) are the most credible climate simulators that have been used in ecosystem studies [35, 47]. In this study, climate projections from the average of 9 AOGCMs, used in the Intergovernmental Panel on Climate Change (IPCC) Fifth Assessment Report (AR5), are applied to assess potential climate change impacts on LAI (Table 3). RCP2.6 and RCP 8.5 are emission scenarios chosen in this study [30, 54]. These scenarios were used because RCP 2.6 and RCP 8.5 scenarios cover the minimum and maximum conditions of the emission scenarios in the future, respectively.

\subsubsection{Preparing climate model scenarios}

To create a climate change scenario for each AOGCM, the delta method was used (Eqs. 4, 5, and 6).

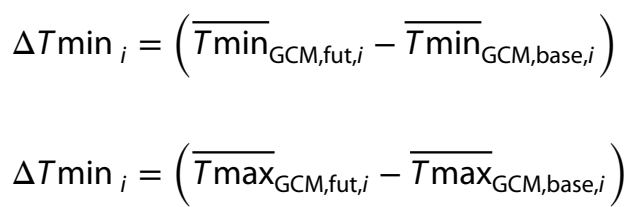

$\Delta P_{i}=\left(\bar{P}_{\mathrm{GCM}, \mathrm{fut}, i} / \bar{P}_{\mathrm{GCM}, \text { base }, i}\right)$

\section{SN Applied Sciences}


Table 3 Description of AOGCMs used in this study

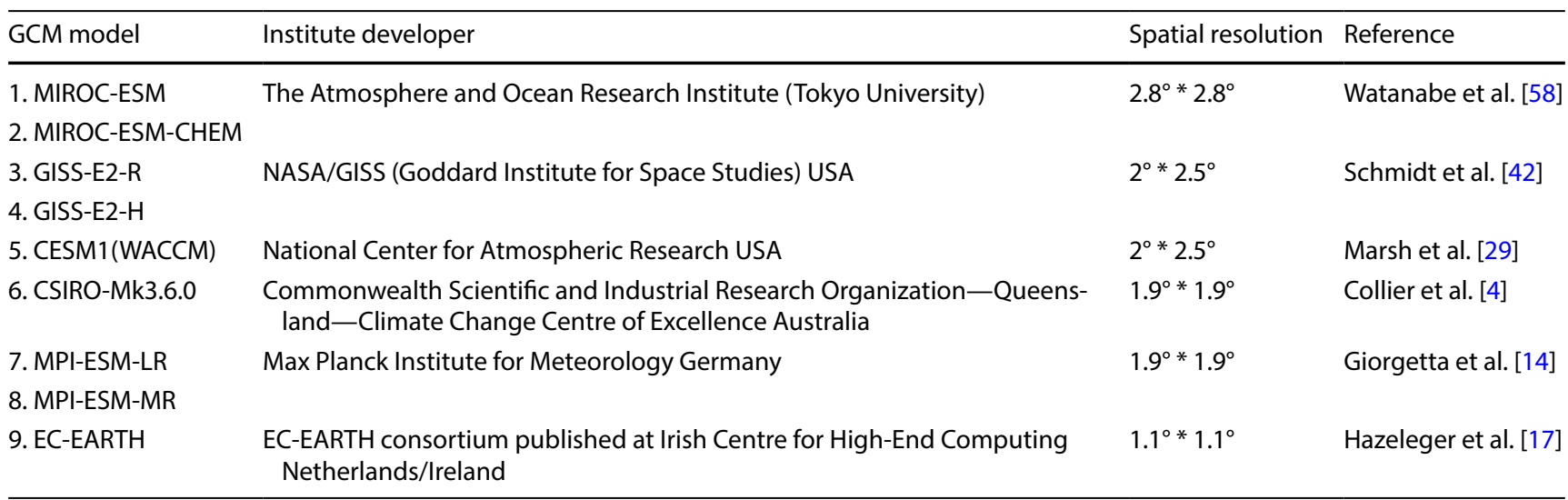

In the above equations, $\Delta T \min _{i}, \Delta T \max _{i}$, and $\Delta P_{i}$ represent the changes in the amount of minimum temperature, maximum temperature, and precipitation, respectively, for the future period (2020-2039) relative to the baseline period (1986-2005) in each month $(1 \leq i \leq 12)$. Also, $\left(\overline{T \min }_{\mathrm{GCM}, \mathrm{fut}, i}\right),\left({\overline{T \max _{\mathrm{GCM}, \mathrm{fut}, i}}}_{\mathrm{i}}\right)$, and $\left(\bar{P}_{\mathrm{GCM}, \mathrm{fut}, i}\right)$ are 20-year average simulated minimum and maximum temperature and precipitation for each month in

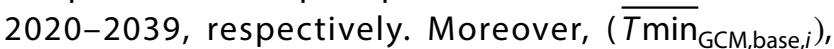
$\left(\overline{T m a x}_{\mathrm{GCM}, \text { base }, i}\right)$, and $\left(\bar{P}_{\mathrm{GCM}, \text { base }, i}\right)$ are 20 -year average observed minimum and maximum temperature and precipitation for each month in the baseline period (1986-2005), respectively [19].

Then, the ensemble average climate change scenarios of 9 AOGCMs were calculated for minimum temperature, maximum temperature, and precipitation in the future period (2020-2039) relative to the baseline period (1986-2005) (Eqs. 7, 8, and 9).

$\Delta T \min (\text { ensemble })_{i}=\sum_{j=1}^{n}\left(\Delta T \min _{i}\right) / n$

$\Delta T \max (\text { ensemble })_{i}=\sum_{j=1}^{n}\left(\Delta T \max _{i}\right) / n$

$\Delta P(\text { ensemble })_{i}=\sum_{j=1}^{n}\left(\Delta P_{i}\right) / n$

In the above equations, $\Delta T \min \left(\right.$ ensemble) ${ }_{i}$ $\Delta T \max (\text { ensemble })_{i}$, and $\Delta P$ (ensemble $)_{i}$ represent the ensemble average climate change scenarios for minimum temperature, maximum temperature, and precipitation in each month $(12 \geq i \geq 1)$. Also, $(n)$ is the number of AOGCMs.

\subsubsection{LARS-WG model}

To introduce daily climate data to the BIOME-BGC model in the future period (2020-2039) under the climate change scenarios, a weather generator model called LARS-WG was used [2]. LARS-WG model (version 5.5) is a stochastic weather generator which is useful for generating the daily time series of maximum and minimum temperatures (degrees Celsius) and precipitation (millimeters) in a climate station under current and future climate conditions $[36,41]$.

The modeling processes using LARS-WG model are composed of three main steps, including calibration, evaluation, and generation of meteorological data for the future. In the calibration step, the probabilistic distribution parameters of the observed daily climate variable (1986-2005), including daily maximum and minimum temperatures and precipitation, were analyzed and computed. In the second step, the ability of the LARS-WG model to simulate daily climate data during the baseline period (1986-2005) was evaluated by comparing observed and simulated climate data. In the third step, by introducing the ensemble average climate change scenario under RCP2.6 and RCP8.5 emission scenarios created by Eqs. (7), (8), and (9), daily climate data for 2020-2039 were generated under future climate conditions.

\section{Results and discussion}

\subsection{Evaluation results of BIOME-BGC model}

The monthly LAI values were simulated by BIOME-BGC in 319 pixels separately over the Kasilian catchment. The 
(a)

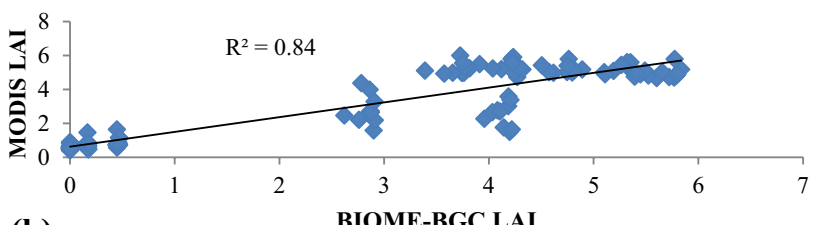

(b)

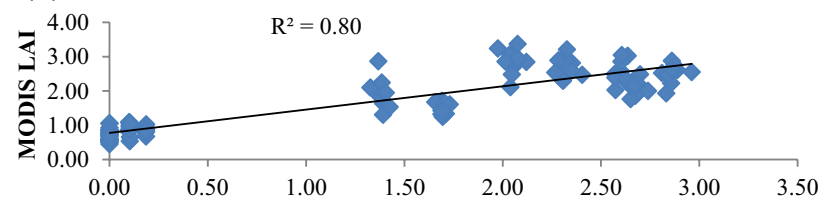

(c)

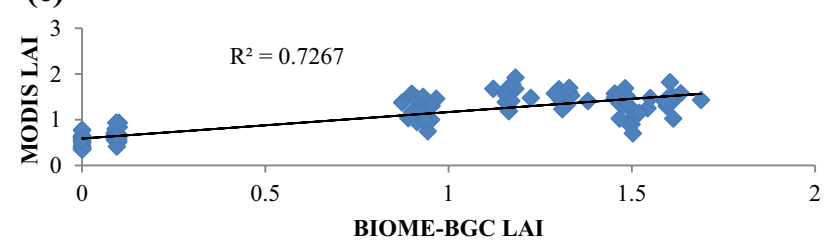

Fig. 3 Scatterplots of monthly MODIS LAI and BIOM-BGC LAI at three different pixels (a DBF, $\mathbf{b}$ shrub and $\mathbf{c}$ C3 grasses)

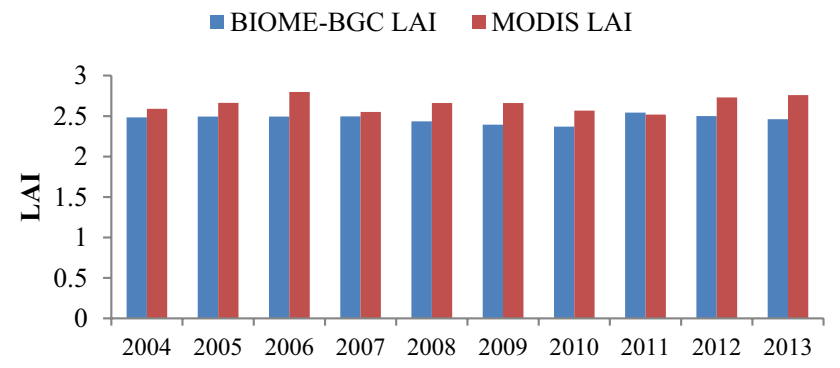

Fig. 4 Comparison of annual mean LAI derived from MODIS and BIOME-BGC model over the Kasilian catchment

amount of calculated $R^{2}$ is greater than or equal to 0.7 $\left(R^{2} \geq 0.7\right)$ in all pixels which demonstrate that monthly MODIS LAI and BIOME-BGC LAI were in good agreement. As an example, the scatterplot of the monthly MODIS LAI and BIOME-BGC LAI for three pixels including deciduous broadleaf forest (DBF), shrubs, and $\mathrm{C} 3$ grasses is shown in Fig. 3a, b, c, respectively. Although the $R^{2}$ values indicate an acceptable correlation between monthly MODIS LAI and BIOME-BGC LAI, the values of percentage error (PE) and RMSE show a small amount of error between these two LAl time series. The PE and RMSE values in all pixels were less than or equal to $30 \%$ and 0.9 , respectively. This error is resulted from the inability of BIOME-BGC model to simulate the rapid growth of plants in the early part of the growing season. Furthermore, the comparison of the annual mean values of the MODIS LAI and BIOME-BGC LAI showed a slight discrepancy from 2004 to 2013 (Fig. 4). Figure 4 also demonstrates that BIOME-BGC model simulated the annual mean LAI values with high accuracy in all years.

\subsection{Changes in climate variables and $\mathrm{CO}_{2}$ level}

Monthly changes of minimum temperature, maximum temperature, and precipitation in the future period (2020-2039) relative to the baseline period (1986-2005), calculated based on Eqs. (7), (8), and (9), are shown in Fig. 5a, b, c, respectively. The results showed that minimum and maximum temperature would increase under both scenarios (RCP2.6 and RCP8.5) in all months. Under both scenarios, minimum and maximum temperatures are expected to increase more in May, June, July, August, and September compared to other months in the future period. It is also projected that minimum and maximum temperatures under the RCP8.5 scenario will see a higher increase compared to the RCP2.6 scenario in all months, with an exception in February and March.

The percentage of precipitation will increase in half of the months and decrease in the rest of the months. Precipitation changes will be negative from February to August. For example, the highest precipitation fall in both scenarios is related to May and July, when precipitation will see a reduction of more than $10 \%$. In contrast, the highest precipitation increase is expected to occur in June (more than 30\%) and in September (more than 50\%) under the RCP2.6. It is projected that the average temperature over the Kasilian catchment will be increased by $1.1^{\circ} \mathrm{C}$ and $1.3^{\circ} \mathrm{C}$ under RCP2.6 and RCP8.5 scenarios, respectively. Moreover, average precipitation in Kasilian catchment will rise by $5.5 \%$ and $1.3 \%$ under RCP 2.6 and RCP 8.5 scenarios. In addition, based on annual time series of carbon dioxide derived from IPCC website (www.IPCC-data.org), carbon
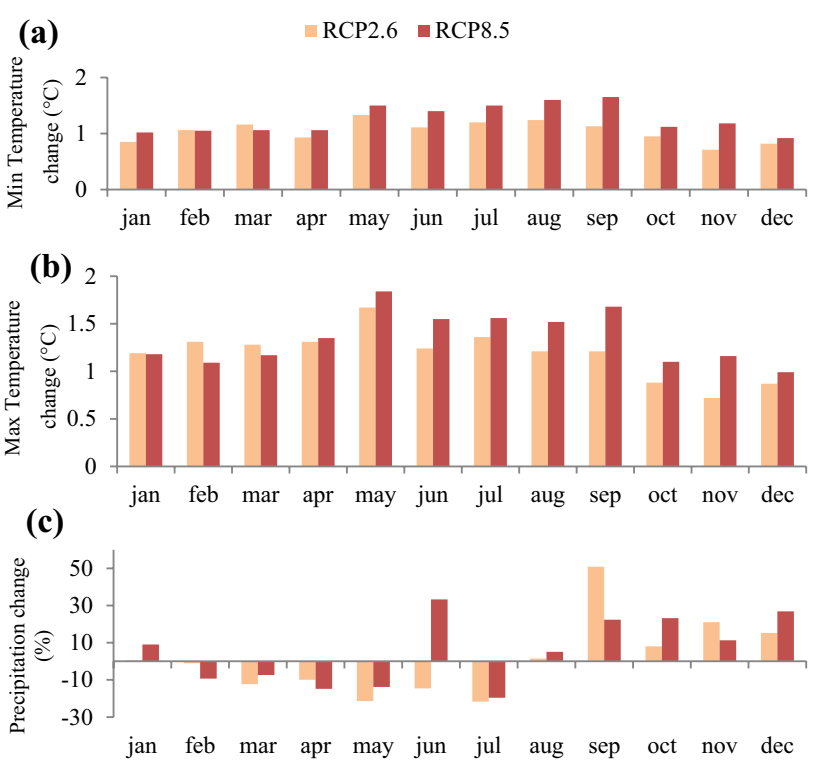

Fig. 5 Changes in MIN temperature $\mathbf{a}$ and maximum temperature $\mathbf{b}$ and precipitation c resulted from nine ensembles AOGCMs AR5 in (2020-2039) relative to (1986-2005) 


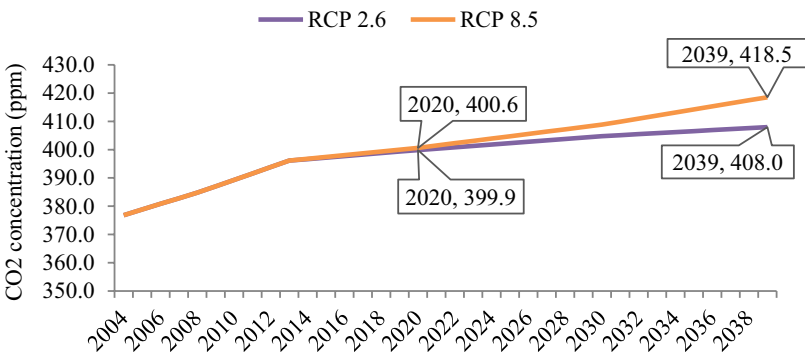

Fig. 6 Changes of $\mathrm{CO}_{2}$ level from 2004 to 2039

dioxide concentration under RCP2.6 and RCP8.5 scenarios will increase by +18 ppm and + 23 ppm in Iran from 2020 to 2039 , respectively (Fig. 6).

\subsection{Evaluation of the LARS-WG model}

Figure 7a, b, c shows scatterplots between monthly mean values of minimum temperature, maximum temperature, and precipitation simulated by the LARS-WG model and observed data at "Darzikola" climatology station located in the Kasilian catchment during the baseline period (1986-2005). The high value of $R^{2}$ between observed and simulated monthly mean minimum temperature, maximum temperature, and precipitation indicates that LARS-WG model regenerates climate variables with high accuracy at "Darzikola" climatology station. $R^{2}$ value for monthly mean minimum and the maximum temperature is more than 0.99 , and for monthly mean precipitation it is about 0.86 . It represents that simulated monthly mean precipitation values have a relatively lower accuracy compared to simulated monthly mean minimum and maximum temperature.
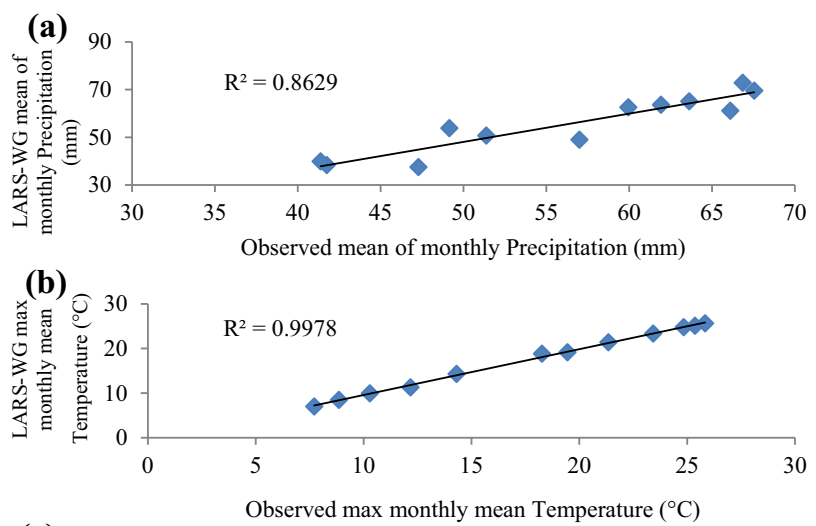

(c)

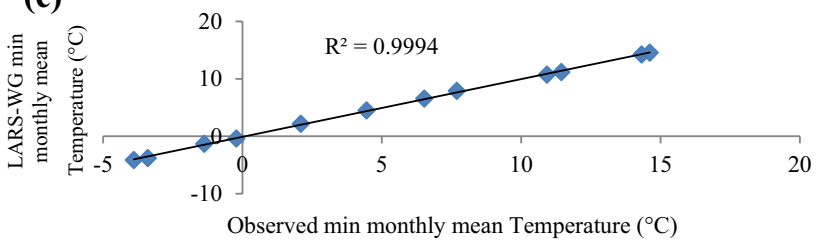

Fig. 7 LARS-WG monthly mean climate variables against observed monthly mean climate variables in the baseline period (19862005). a Precipitation, b maximum temperature and c minimum temperature

Table 4 shows probability values ( $P$ value) calculated by $T$ test between the observed and simulated monthly mean minimum and maximum temperature and precipitation. It also shows $P$ values calculated by Kolmogorov-Smirnov test (KS) between probabilistic distributions of observed and simulated daily minimum and maximum temperature and precipitation. Calculated $p$ values by the $T$ test and KS test are above 0.1 in all months. Therefore, the null hypothesis for the $T$ test and KS test is significant at $10 \%$ level for minimum and maximum temperatures and
Table 4 The evaluation result of LARS-WG ability to simulate climate variables in "Darzikola" climatology station located in Kasilian catchment

\begin{tabular}{|c|c|c|c|c|c|c|}
\hline \multirow[t]{2}{*}{ Month } & \multicolumn{3}{|c|}{$P$ value of KS test for daily distributions } & \multicolumn{3}{|c|}{$\begin{array}{l}P \text { value of } T \text { test for monthly distribu- } \\
\text { tions }\end{array}$} \\
\hline & PRCP & $T \min$ & $T \max$ & PRCP & $T \min$ & $T \max$ \\
\hline JAN & 1.00 & 1.00 & 0.99 & 0.18 & 0.92 & 0.93 \\
\hline FEB & 1.00 & 1.00 & 0.79 & 0.13 & 0.69 & 0.37 \\
\hline MAR & 1.00 & 1.00 & 0.63 & 0.30 & 0.46 & 0.16 \\
\hline APR & 1.00 & 1.00 & 0.79 & 0.41 & 0.64 & 0.35 \\
\hline MAY & 1.00 & 1.00 & 0.95 & 0.75 & 0.95 & 0.73 \\
\hline JUN & 1.00 & 1.00 & 0.65 & 0.63 & 0.12 & 0.76 \\
\hline JUL & 1.00 & 1.00 & 0.98 & 0.87 & 0.28 & 0.58 \\
\hline AUG & 1.00 & 1.00 & 0.74 & 0.47 & 0.73 & 0.91 \\
\hline SEP & 1.00 & 1.00 & 0.65 & 0.42 & 0.57 & 0.76 \\
\hline OCT & 1.00 & 1.00 & 1.00 & 0.38 & 0.64 & 0.78 \\
\hline NOV & 1.00 & 1.00 & 0.54 & 0.87 & 0.97 & 0.88 \\
\hline DEC & 1.00 & 1.00 & 0.68 & 0.71 & 0.56 & 0.79 \\
\hline
\end{tabular}


precipitation in all the months. This means that daily and monthly observed and simulated values had a similar statistical distribution. Results mentioned in this section show that the LARS-WG model has a high capability to simulate daily and monthly minimum temperature, maximum temperature, and precipitation at "Darzikola" climatology station. After evaluating the LARS-WG model, daily climate variables in the future period (2020-2039) were generated under climate scenarios mentioned in Sect. 4.3.

\subsection{LAI changes under climate change}

By introducing daily climate series generated by the LARSWG model and annual level of $\mathrm{CO}_{2}$ derived from IPCC website (www.IPCC-data.org) to BIOME-BGC model, daily LAI series were estimated under RCP2.6 and RCP8.5 in the future period (2020-2039) in all pixels. Figure 8 shows percentage changes in monthly LAI in all pixels in response to changes in climate variables of temperature, precipitation and carbon dioxide concentration ( $\mathrm{ppm}$ ) under the RCP2.6 and RCP8.5 scenarios during the future period (2020-2039) compared to the study period (2004-2013).

Based on Fig. 8, LAl is expected to increase in all pixels under both scenarios. Also, it is demonstrated that LAI under RCP8.5 will rise more than under RCP2.6 in all pixels. The highest rise of LAI under RCP2.6 and RCP 8.5 will be about 2.8 and $4 \%$, and the least rise of LAI under RCP2.6 and RCP8.5 is expected to be $0.3 \%$ and $1.1 \%$, respectively. Under both scenarios, the highest increase in LAl will be related to pixels with DBF located in center and north of the catchment, and also pixels with shrubs and $\mathrm{C} 3$ grasses located in the south of the basin. LAI in these pixels will increase between 2 and $2.8 \%$ under RCP2.6 and between 3 and $4 \%$ under RCP8. In contrast, the least increase in LAl, less than $1 \%$, will occur in pixels with DBF located in the southern parts of the catchment under both scenarios.

Based on the data shown in Table 5, it is clear that Kasilian catchment average LAI in pixels with DBF will have

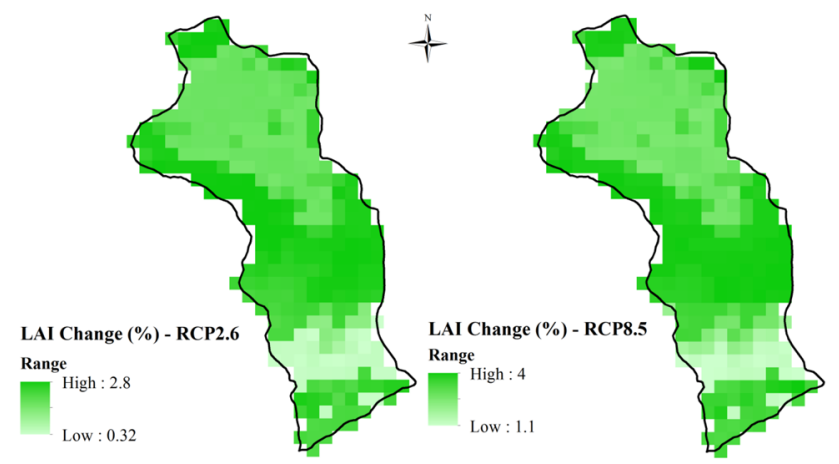

Fig. 8 Percentage of LAl change in the future period (2020-2039) relative to the study period (2004-2013) under RCP2.6 and RCP8.5, in all pixels within Kasilian catchment domain
Table 5 The percentage changes in the average LAl under the two RCPs in the future period (2020-2039) compared to the study period (2004-2013) in DBF, shrubs, and C3 grasses pixels

\begin{tabular}{llll}
\hline RCPs & DBF & Shrubs & C3 grasses \\
\hline RCP2.6 & +2.2 & +1.9 & +1.9 \\
RCP8.5 & +3.2 & +2.9 & +2.8 \\
\hline
\end{tabular}

higher increase rather than that of pixels with shrubs and C3 grasses under both scenarios. It indicates that DBF will be more sensitive to changes in climate variables and the $\mathrm{CO}_{2}$ level compared to shrubs and $\mathrm{C}_{3}$ grasses in the case study. The behavior of shrubs and $\mathrm{C} 3$ grasses will be almost similar in response to climate and $\mathrm{CO}_{2}$ changes.

Figure 9 shows the changes in monthly average LAI over the Kasilian catchment. As shown in Fig. 9, LAl will increase in response to climate and carbon dioxide level change in all months, especially in spring and summer. Also, LAI will experience a higher rise under the RCP8.5 compared to RCP2.6 in all months. The highest increase in LAl will occur in May under both scenarios.

Overall, our results showed that average LAI in the Kasilian catchment will increase by about $2.2 \%$ and $3.1 \%$ under RCP2.6 and RCP 8.5 in the future period (2020-2039) relative to the study period (2004-2013). These results demonstrate that the projected increase in both temperature and precipitation (mentioned in Sect. 4.2) is likely to have a positive impact on LAI growth in the Kasilian catchment, while another study conducted in Australia showed that LAI is expected to decrease for three land covers (crop, pasture, and tree) in response to increase in mean monthly temperature and a general decrease in precipitation under four scenarios (RCP2.6, RCP4.5, RCP6, and RCP8) [49]. This comparison shows that LAI behavior in response to climate change varies from region to region, and it depends on the condition of climate variables in the future. Therefore, investigating LAI behavior in each particular region would be necessary, and the approach applied here can be used in other studies.

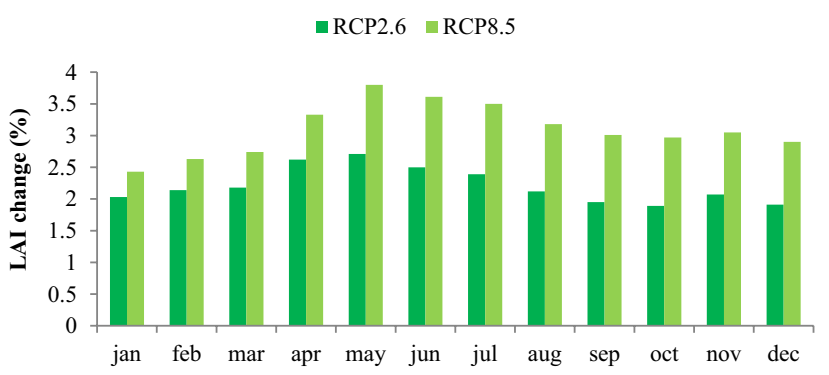

Fig. 9 Monthly Kasilian catchment average LAl changes in the future period (2020-2039) relative to the study period (2004-2013) 
To calculate the accurate impact of $\mathrm{LAl}$ increase $(2.2 \%$ and $3.1 \%$ under RCP2.6 and RCP8.5) on the amount of runoff in the Kasilian catchment, projected LAI data should be coupled with hydrologic models. A slight increase in LAl may not have a great impact on the particular amount of runoff, but the seasonal or annual amount of runoff would change a lot $[48,59]$. Therefore, our approach can be used by hydrologists to assess the impact of dynamic LAI on the amount of water balance in other regions.

\section{Conclusion}

In this study, a new framework is presented to investigate future LAI changes over Kasilian catchment located in the north of Iran in response to climate change using an ecological model named as BIOME-BGC model. AOGCMs projections show an overall increase in mean temperature $\left(+1.1{ }^{\circ} \mathrm{C}\right.$ under RCP2.6 and $+1.3{ }^{\circ} \mathrm{C}$ under RCP8.5) and precipitation $(+5.5 \%$ under RCP2.6 and $+1.3 \%$ under RCP8.5) during the future period (2020-2039) compared to the baseline period (1986-2005). These results indicate that climate conditions are expected to be warmer under RCP8.5 and more humid under RCP2.6 across the region. In addition, the concentration of $\mathrm{CO}_{2}$ will rise by $+18 \mathrm{ppm}$ and +23 ppm under RCP2.6 and RCP8.5 between 2004 and 2039, respectively. Model outputs illustrate that the catchment mean LAI will increase by $2.2 \%$ and $3.1 \%$ under RCP2.6 and RCP8.5 during the future period (2020-2039), respectively. The study shows the vegetation feedback is more sensitive in response to temperature change compared to precipitation change. Therefore, RCP8.5 will experience higher LAI than RCP2.6.

There are two sources of uncertainty in this paper. We used satellite-derived LAI (MODIS LAI) for assessing the accuracy of BIOME-BGC LAI outputs, while estimated LAI derived from satellite imagery is not quite accurate. Moreover, due to the uncertainty of AOGCMs in the simulation of climate variables in the future, forecasted LAI has also an uncertainty. However, overall, these predictions can provide an appropriate pattern from changes in vegetation cover conditions in the future in catchments. The results of this study could be associated with hydrologic models to investigate the vegetation dynamic behavior and climate change on the hydrologic behavior of the Kasilian catchment.

Acknowledgements We are grateful to the Numerical Terradynamic Simulation Group (NTSG) at the University of Montana, USA, for freely sharing the BIOME-BGC model at https://www.ntsg.umt.edu/data.
Funding Ali Reza Massah Bavani received research grant from the University of Tehran.

\section{Compliance with ethical standards}

Conflict of interest The authors declare that they have no conflict of interest.

\section{References}

1. Baret $F$, Hagolle $O$, Geiger B, Bicheron $P$, Miras $B$, Huc $M$, Berthelot B, Niño F, Weiss M, Samain O, Roujean JL (2007) LAI, fAPAR and fCover CYCLOPES global products derived from VEGETATION: part 1: principles of the algorithm. Remote Sens Environ 110:275-286

2. Chen H, Guo J, Zhang Z, Xu CY (2013) Prediction of temperature and precipitation in Sudan and South Sudan by using LARS-WG in future. Theor Appl Climatol 113:363-375

3. Chen JM, Black TA (1992) Defining leaf area index for non-flat leaves. Plant Cell Environ 15:421-429

4. Collier MA, Jeffrey SJ, Rotstayn LD,Wong KK, Dravitzki SM, Moseneder C, Hamalainen C, Syktus Jl, Suppiah R, Antony J, El Zein A, Artif M (2011) The CSIRO-Mk3.6.0 Atmosphere-Ocean GCM: participation in CMIP5 and data publication. In: International congress on modelling and simulation-MODSIM 2011, The 19th international congress on modelling and simulation (MODSIM2011) was held at the Perth Convention and Exhibition Centre in Perth, Perth, Western Australia, 12-16 December 2011

5. Davoodi E, Ghasemieh H, Batelaan O, Abdollahi K (2017) Spatial-temporal simulation of $\mathrm{LAI}$ on basis of rainfall and growing degree days. Remote Sens 9:1207. https://doi.org/10.3390/rs912 1207

6. Dong T, Liu J, Qian B, Zhao T, Jing Q, Geng X, Shang J (2016) Estimating winter wheat biomass by assimilating leaf area index derived from fusion of Landsat-8 and MODIS data. Int J Appl Earth Obs Geoinf 49:63-74

7. Donohue RJ, Roderick ML, McVicar TR (2006) On the importance of including vegetation dynamics in Budyko? s hydrological model. Hydrol Earth Syst Sci Discuss 3:1517-1551

8. Fang $\mathrm{H}$, Wei S, Liang $\mathrm{S}$ (2012) Validation of MODIS and CYCLOPES LAl products using global field measurement data. Remote Sens Environ 119:43-54

9. Friedl MA, Sulla-Menashe D, Tan B, Schneider A, Ramankutty N, Sibley A, Huang X (2010) MODIS collection 5 global land cover: algorithm refinements and characterization of new datasets. Remote Sens Environ 114:168-182

10. Ganguly S, Samanta A, Schull MA, Shabanov NV, Milesi C, Nemani RR, Gao F, Masuka E, Myneni R, Tan B, Nightingale J (2008) An algorithm to produce temporally and spatially continuous MODIS-LAI time series. IEEE Geosci Remote Sens Lett 1:1545-1598

11. Gholami V, Jokar E, Azodi M, Zabardast HA, Bashirgonbad M (2009) The influence of anthropogenic activities on intensifying runoff generation and flood hazard in Kasilian watershed. $J$ Appl Sci 9:3723-3730

12. Gholzom EH, Gholami V (2012) A comparison between natural forests and reforested lands in terms of runoff generation potential and hydrologic response (case study: kasilian watershed). Soil Water Res 7:166-173

13. Gigante V, lacobellis V, Manfreda S, Milell P, Portoghese I (2009) Influences of Leaf Area Index estimations on water balance modeling in a Mediterranean semi-arid basin. Nat Hazards Earth Syst 9:979-991 
14. Giorgetta MA, Jungclaus J, Reick $\mathrm{CH}$, Legutke $\mathrm{S}$, Bader J, Böttinger M, Brovkin V, Crueger T, Esch M, Fieg K, Glushak K (2013) Climate and carbon cycle changes from 1850 to 2100 in MPIESM simulations for the Coupled Model Intercomparison Project phase 5. J Adv Model Earth Syst 5:572-597

15. Hardwick SR, Toumi R, Pfeifer M, Turner EC, Nilus R, Ewers RM (2015) The relationship between leaf area index and microclimate in tropical forest and oil palm plantation: forest disturbance drives changes in microclimate. Agric For Meteorol 201:187-195

16. Hao L, Pan C, Liu P, Zhou D, Zhang L, Xiong Z, Sun G (2016) Detection of the coupling between vegetation leaf area and climate in a multifunctional watershed, Northwestern China. Remote Sens 81:1032. https://doi.org/10.3390/rs8121032

17. Hazeleger W, Severijns $C$, Semmler T, Ştefănescu S, Yang $S$, Wang X, Wyser K, Dutra E, Baldasano JM, Bintanja R, Bougeault $P$ (2010) EC-Earth: a seamless earth-system prediction approach in action. Bull Am Meteorol Soc 91:1357-1364

18. Idso SB (1988) Three phases of plant response to atmospheric CO2 enrichment. Plant Physiol 87:5-7

19. Jones PD, Hulme M (1996) Calculating regional climatic time series for temperature and precipitation: methods and illustrations. Int J Climatol 16:361-377

20. Kang S, Running SW, Kimball JS, Fagre DB, Michaelis A, Peterson DL, Hong $S$ (2014) Effects of spatial and temporal climatic variability on terrestrial carbon and water fluxes in the Pacific Northwest, USA. Environ Model Softw 51:228-239

21. Khaleghi MR (2017) The influence of deforestation and anthropogenic activities on runoff generation. J For Sci 63:1-9

22. Kim JB, Monier E, Sohngen B, Pitts GS, Drapek R, McFarland J, Ohrel S, Cole J (2017) Assessing climate change impacts, benefits of mitigation, and uncertainties on major global forest regions under multiple socioeconomic and emissions scenarios. Environ Res Lett 12:045001. https://doi.org/10.1088/1748-9326/ aa63fc

23. Kimball BA, Idso SB (1983) Increasing atmospheric $\mathrm{CO}_{2}$ : effects on crop yield, water use and climate. Agric Water Manag 7:55-72

24. Krishnaswamy J, John R, Joseph S (2014) Consistent response of vegetation dynamics to recent climate change in tropical mountain regions. Glob Change Biol 20:203-215

25. Krinner G, Viovy N, de Noblet-Ducoudré N, Ogée J, Polcher J, Friedlingstein P, Ciais P, Sitch S, Prentice IC (2005) A dynamic global vegetation model for studies of the coupled atmosphere-biosphere system. Glob Biogeochem Cycles. https://doi. org/10.1029/2003GB002199

26. Kross A, Lapen DR, McNarin H, Sunohara M, Champagne $C$, Wilkes $G$ (2015) Satellite and in situ derived corn and soybean biomass and leaf area index: response to controlled tile drainage under varying weather conditions. Agric Water Manag 160:118-131

27. Mahowald N, Lo F, Zheng Y, Harrison L, Funk C, Lombardozzi D, Goodale C (2016) Projections of leaf area index in earth system models. Earth Syst Dyn 7:211-229

28. Manea A, Leishman MR (2014) Leaf area index drives soil water availability and extreme drought-related mortality under elevated $\mathrm{CO}_{2}$ in a temperate grassland model system. PLoS ONE 9:91046. https://doi.org/10.1371/journal.pone.0091046

29. Marsh DR, Mills MJ, Kinnison DE, Lamarque JF, Calvo N, Polvani LM (2013) Climate change from 1850 to 2005 simulated in CESM1 (WACCM). J Clim 26:7372-7391

30. Moss RH, Edmonds JA, Hibbard KA, Manning MR, Rose SK, Van Vuuren DP, Carter TR, Emori S, Kainuma M, Kram T, Meehl GA (2010) The next generation of scenarios for climate change research and assessment. Nature 463:747. https://doi. org/10.1038/nature08823
31. Myneni RB, Hoffman S, Knyazikhin Y, Privette JL, Glassy J, Tian Y, Wang Y, Song X, Zhang Y, Smith GR, Lotsch A, FriedI M, Morisette JT, Votava P, Nemani RR, Running SW (2002) Global products of leaf area index and fraction absorbed PAR from year one of MODIS data. Remote Sens Environ 83:214-231

32. Myneni R, Knyazikhin Y, Park T (2015) MOD15A2H MODIS/Terra Leaf Area Index/FPAR 8-Day L4 Global 500 m SIN Grid V006 [Data set]. NASA EOSDIS Land Processes DAAC, https://doi. org $/ 10.5067 / \mathrm{modis} / \mathrm{mod} 15 \mathrm{a} 2 \mathrm{~h} .006$

33. Nielsen DC, Miceli-Garcia JJ, Lyon DJ (2012) Canopy cover and leaf area index relationships for wheat, triticale, and corn. Agron J 104:1569-1573

34. Piao S, Yin G, Tan J, Cheng L, Huang M, Li Y, Liu R, Mao J, Myneni RB, Peng S, Poulter B (2015) Detection and attribution of vegetation greening trend in China over the last 30 years. Glob Change Biol 21:1601-1609

35. Pourmokhtarian A, Driscoll CT, Campbell JL, Hayhoe K, Stoner AM, Adams MB, Burns D, Fernandez I, Mitchell MJ, Shanley JB (2017) Modeled ecohydrological responses to climate change at seven small watersheds in the northeastern United States. Glob Change Biol 23:840-856

36. Racsko P, Szeidl L, Semenov M (1991) A serial approach to local stochastic weather models. Ecol Model 57:27-41

37. Ramezani MR, Massah Bavani AR, Jafari M, Binesh A (2017) Evaluating gridded BIOME-BGC for simulating LAI at Kasilian watershed-Iran. Geol Ecol Landsc 1:225-231

38. Ran L, Pleim J, Gilliam R, Hogrefe C, Binkowski F, Band L (2016) Application and evaluation of MODIS LAI, FPAR, and Albedo products in the WRF/CMAQ System. In: Steyn DG, Chaumerliac N (eds) Air pollution modeling and its Application XXIV. Springer, Berlin, pp 619-624

39. Running SW, Hunt ER (1993) Generalization of a forest ecosystem process model for other biomes, BIOME-BGC, and an application for global-scale models. In: Ehleringer JR, Field CB (eds) Scaling physiological processes: leaf to globe. Academic Press, San Diego, pp 141-158

40. Running SW, Nemani RR (1991) Regional hydrologic and carbon balance responses of forests resulting from potential climate change. Clim Change 19:349-368

41. Semenov MA, Brooks RJ, Barrow EM, Richardson CW (1998) Comparison of the WGEN and LARS-WG stochastic weather generators for diverse climates. Clim Res 10:95-107

42. Schmidt GA, Kelley M, Nazarenko L, Ruedy R, Russell GL, Aleinov I, Bauer M, Bauer SE, Bhat MK, Bleck R, Canuto V (2014) Configuration and assessment of the GISS ModelE2 contributions to the CMIP5 archive. J Adv Model Earth Syst 6:141-184

43. Sitch S, Smith B, Prentice IC, Arneth A, Bondeau A, Cramer W, Thonicke K (2003) Evaluation of ecosystem dynamics, plant geography and terrestrial carbon cycling in the LPJ dynamic global vegetation model. Glob Change Biol 9:161-185

44. Srebin PS, AhI DE, Gower ST (2013) Spatial and temporal validation of the MODIS LAI and FPAR products across a boreal forest wildfire chronosequence. Remote Sens Environ 133:71-84

45. Stenberg P (1996) Correcting LAl-2000 estimates for the clumping of needles in shoots of conifers. Agric For Meteorol 79:1-8

46. Stocker TF, Qin D, Plattner GK, Tignor M, Allen SK, Boschung J, Nauels A, Xia Y, Bex V, Midgley PM (2013) IPCC climate change 2013: the physical science basis, contribution of working group I to the fifth assessment report of the intergovernmental panel on climate change. Cambridge University Press, Cambridge

47. Sun S, Sun G, Cohen E, McNulty SG, Caldwell PV, Duan K, Zhang Y (2016) Projecting water yield and ecosystem productivity across the United States by linking an ecohydrological model to WRF dynamically downscaled climate data. Hydrol Earth Syst Sci 20:935-952 
48. Tesemma ZK, Wei Y, Peel MC, Western AW (2015) The effect of year-to-year variability of leaf area index on Variable Infiltration Capacity model performance and simulation of runoff. Adv Water Resour 83:310-322

49. Tesemma ZK, Wei Y, Western AW, Peel MC (2014) Leaf area index variation for crop, pasture, and tree in response to climatic variation in the Goulburn-Broken catchment, Australia. J Hydrometeorol 15:1592-1606

50. Thornton PE, Hasenauer $\mathrm{H}$, White MA (2000) Simultaneous estimation of daily solar radiation and humidity from observed temperature and precipitation: an application over complex terrain in Austria. Agric For Meteorol 104:255-271

51. Thornton PE, Law BE, Gholz HL, Clark KL, Falge E, Ellsworth DS, Chen J (2002) Modeling and measuring the effects of disturbance history and climate on carbon and water budgets in evergreen needleleaf forests. Agric For Meteorol 113:185-222

52. Thornton PE, Rosenbloom NA (2005) Ecosystem model spin-up: estimating steady state conditions in a coupled terrestrial carbon and nitrogen cycle model. Ecol Model 189:25-48

53. Trombetta A, Lac obellis V, Tarantino U, Gentile F (2016) Calibration of the AquaCrop model for winter wheat using MODIS LAI images. Agric Water Manag 164:304-316

54. Van Vuuren DP, Edmonds J, Kainuma M, Riahi K, Thomson A, Hibbard K, Hurtt GC, Kram T, Krey V, Lamarque JF, Masui T (2011) The representative concentration pathways: an overview. Clim Change 109:5. https://doi.org/10.1007/s10584-011-0148-z

55. Wang J, Hiroshi I, Ning S, Khujanazarov T, Yin G, Guo L (2016) Attribution analyses of impacts of environmental changes on streamflow and sediment load in a mountainous basin, Vietnam. Forests 7:30

56. Wang YP, Law RM, Pak B (2010) A global model of carbon, nitrogen and phosphorus cycles for the terrestrial biosphere. Biogeosciences 7:2261-2282

57. White MA, Thornton PE, Running SW, Nemani RR (2000) Parameterization and sensitivity analysis of the BIOME-BGC terrestrial ecosystem model: net primary production controls. Earth Interact 4:1-85

58. Watanabe $S$, Hajima T, Sudo K, Nagashima T, Takemura T, Okajima H, Nozawa T, Kawase H, Abe M, Yokohata T, Ise T (2011)
MIROC-ESM 2010: model description and basic results of CMIP5-20c3m experiments. Geosci Model Dev 4:845. https:// doi.org/10.5194/gmd-4-845-2011

59. Wu XX, Gu ZJ, Luo H, Shi XZ, Yu DS (2014) Analyzing forest effects on runoff and sediment production using Leaf Area Index. Mt Sci 11:119-130

60. Xiao Z, Liang S, Sun R, Wang J, Jiang B (2015) Estimating the fraction of absorbed photosynthetically active radiation from the MODIS data based GLASS leaf area Index product. Remote Sens Environ 171:105-117

61. Yan K, Park T, Yan G (2016) Evaluation of MODIS LAI/FPAR product collection 6. Remote Sens 8:460-486

62. Yang $W$, Tan $B$, Huang $D$, Rautiainen $M$, Shabanov NV, Wang $Y$, Privette JL, Huemmrich KF, Fensholt R, Sandholt I, Weiss M (2006) MODIS leaf area index products: from validation to algorithm improvement. IEEE Trans Geosci Remote Sens 44:1885-1898

63. Yu X, Duffy C, Kaye J, Crow W, Bhatt G, Shi Y, Lakshmi V (2014) Watershed reanalysis of water and carbon cycle models at a critical zone observatory. Remote Sen Terr Water Cycle 206:493-509

64. Zhang J, Walsh JE (2007) Relative impacts of vegetation coverage and leaf area index on climate change in a greener north. Geophys Res Lett. https://doi.org/10.1029/2007GL030852

65. Zhang L, Hickel K, Dawes WR, Chiew FH, Western AW, Briggs PR (2004) A rational function approach for estimating mean annual evapotranspiration. Water Resour Res. https://doi. org/10.1029/2003WR002710

66. Zhang Y, Huang M, Lian J (2015) Spatial distributions of optimal plant coverage for the dominant tree and shrub species along a precipitation gradient on the central Loess Plateau. Agric For Meteorol 206:69-84

Publisher's Note Springer Nature remains neutral with regard to jurisdictional claims in published maps and institutional affiliations. 